\title{
Space traveler
}

Ayol Samuels, MD

Neurology ${ }^{\circledR}$ 2020;94:1038-1039. doi:10.1212/WNL.0000000000009587
Correspondence

Dr. Samuels

ayol.samuels@gmail.com

John Doe sat upright in his bed with a proud grin on his bruised face. He had wandered into the emergency room the night before and seemed to have had a fall. He could not recall his name and no family member was present. The emergency room notes described him as delusional and the patient could not explain why or how he had arrived.

On the inpatient floor, Mr. D was alert and attentive. He explained in a clear and cogent manner that he had been in Florida the day before. He then remembered being taken into a rocket ship and buckled down. He was placed into and out of the space ship by people with special uniforms. "Who were they?" he wondered. "NASA? Aliens?" They placed some sort of tracking device around his wrist, he remembered. The rocket ship took off and now he is here. Where, exactly, he is not sure.

Mr. D took a long look at his bruises. "It was a rough ride," he said. "Lots of banging and not much room." As he left the spaceship, he remembers having had a throbbing headache and feeling sore all over. He could not provide names or numbers of family members, and did not know his medical or psychiatric history. His belongings? They took them from him, he said unemotionally. Couldn't bring them onto the spaceship.

Other than the retrograde and anterograde amnesia and an apathetic affect that was incongruous to his present situation, Mr. D's neurologic exam was largely unremarkable. $\mathrm{He}$ was able to complete serial $7 \mathrm{~s}$, he performed well on executive function tasks, and his visuospatial abilities were intact as well. There was no evidence of any perceptual disturbance nor of any fixed delusional beliefs. Cranial nerves were intact and sensation, strength, and tone were full and symmetric. Reflexes were $2+$ throughout, he had a normal gait, and a negative Romberg sign.

With the little information we had, we surmised that Mr. D was more likely confused and confabulating than psychotic or intoxicated. But what of the specifics of the story? Listening with our "third ear" for subtexts and metaphors, we tried to understand what the patient was telling us. Something around his wrist, people in uniforms, placed in a tight space with banging, a tube that looks kind of like a space ship, no belongings allowed. Could it be that he was talking about being placed in an MRI machine by unfamiliar nurses in uniforms? we wondered. If he came in bruised and with a headache to a different hospital, head imaging would have been a natural part of the diagnostic workup. Going into an MRI machine can be an unsettling experience for anyone, let alone for someone already confused and having difficulty understanding and registering his experiences.

A long shot, we acknowledged, but worth some investigation. We made a few calls to hospitals in the area. On our third and final attempt, we received a surprising response. "Sounds like David Ramirez,"* the nurse informed us. "He wandered out of our hospital yesterday." He had been brought there by his wife 3 days ago. The staff provided us with his wife's phone number, which we immediately called. Greatly relieved that David was found, she recounted what had happened.

She related through tears that David was a healthy man in his 50s, worked as a real estate agent, and had a keen interest in space travel. The 2 of them were on a trip from Florida to celebrate their 20th anniversary. David had planned a special excursion on a $4 \times 4$. While taking a sharp turn on

*Patient name and other identifying factors have been changed to respect confidentiality. 
the dirt path, the car swerved, and David lost control, crashing straight into a tree. "I was wearing a seatbelt; he was not," she remembered. His head hit the dashboard and then he did not respond for about a minute. David's wife called the ambulance and David slowly came back to but could not remember what had happened and complained of a throbbing headache and sore body. This was the reason for his hospital visit.

The initial neurology team evaluated David. Other than David's confusion and amnesia, they found a nonfocal neurologic examination. They were unsure if his memory loss was due solely to posttraumatic amnesia or whether there was some hemorrhage in addition. An MRI showed a frontal subdural hematoma that was just over $1 \mathrm{~cm}$ in thickness with no associated midline shift. Surgical drainage was planned, but then David wandered away from the hospital. Once staff realized, they alerted the police, who began looking for him. How he arrived at our hospital, a 10-minute drive, we don't know.
We arranged surgery for that day and explained to David what we thought had happened to him. When he insisted that he had indeed been on a spaceship for an important mission, we acceded that the mission was almost over. Surgery was successful but it took several days for David to recover his memory. His overall mental recovery was quite good and David was able to return to work after about 2 weeks. Still, he never regained the memory of those days following the accident and continued to refer, with some nostalgia, to the time that he was on some sort of spaceship simulator and was able to pass on very important information to certain people in uniforms.

\section{Study funding}

No targeted funding reported.

\section{Disclosure}

The author reports no disclosures. Go to Neurology.org/N for full disclosures. 


\title{
Neurology
}

\author{
Space traveler \\ Ayol Samuels \\ Neurology 2020;94;1038-1039 \\ DOI 10.1212/WNL.0000000000009587
}

This information is current as of June 8, 2020

\section{Updated Information \& Services}

\section{Subspecialty Collections}

Permissions \& Licensing

Reprints including high resolution figures, can be found at: http://n.neurology.org/content/94/23/1038.full

This article, along with others on similar topics, appears in the following collection(s):

\section{All Cognitive Disorders/Dementia}

http://n.neurology.org/cgi/collection/all_cognitive_disorders_dementia All Education

http://n.neurology.org/cgi/collection/all_education

Clinical neurology history

http://n.neurology.org/cgi/collection/clinical_neurology_history Memory

http://n.neurology.org/cgi/collection/memory

Information about reproducing this article in parts (figures,tables) or in its entirety can be found online at:

http://www.neurology.org/about/about_the_journal\#permissions

Information about ordering reprints can be found online:

http://n.neurology.org/subscribers/advertise

Neurology ${ }^{\circledR}$ is the official journal of the American Academy of Neurology. Published continuously since 1951, it is now a weekly with 48 issues per year. Copyright (O) 2020 American Academy of Neurology. All rights reserved. Print ISSN: 0028-3878. Online ISSN: 1526-632X.

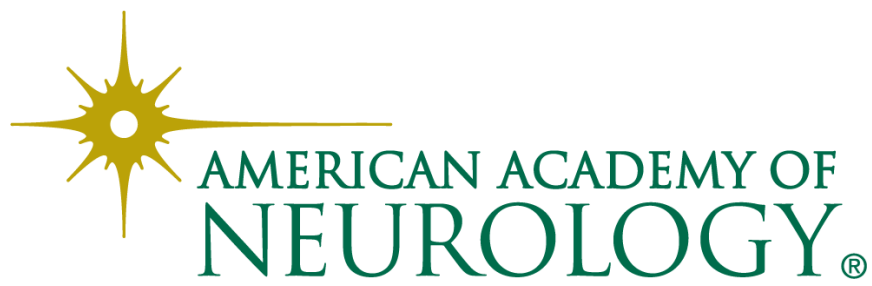

